Dhaka Univ. J. Biol. Sci. 24(1): 1-16, 2015 (January)

\title{
ASSESSMENT OF THE PHYTOAVAILABILITY OF Cu AND Ni USING VARIOUS EXTRACTION PROCEDURES
}

\author{
M.T.A. Chowdhury, L. Nesa And S.M. Imamul HuQ* \\ Bangladesh-Australia Centre for Environmental Research (BACER-DU), Department of Soil, \\ Water and Environment, University of Dhaka, Dhaka-1000, Bangladesh
}

Key words: Heavy metal, Phytoavailability, Single and sequential extraction, Correlation

\begin{abstract}
The phytoavailability of copper $(\mathrm{Cu})$ and nickel $(\mathrm{Ni})$ in soils from Bangladesh was assessed. The uptake by Ipomoea aquatica and Oryza sativa L. was measured and a range of extractants tested on soils and plant tissue samples. Extractants tested were distilled water, $1 \mathrm{M} \mathrm{NH} \mathrm{Nl}_{4}, 0.01 \mathrm{M} \mathrm{CaCl}_{2}, 0.005 \mathrm{M}$ diethylenetriamine penta-acetic acid (DTPA), $0.1 \mathrm{M}$ ethylenediamine tetraacetic acid (EDTA), $0.1 \mathrm{M} \mathrm{HCl}$ and $1 \mathrm{M} \mathrm{HCl}$. The extractability of the metals varied depending on the metal species, the crop and the extractant used. The best extractant was $1 \mathrm{M} \mathrm{HCl}$, which extracted the highest amount of the heavy metals and correlated most strongly with their plant uptake measures. The use of $1 \mathrm{M}$ $\mathrm{HCl}$ is, therefore, recommended for first-level screening of soils contaminated with heavy metals if only one extractant is to be used. Sequential extraction showed that $\mathrm{Cu}$ was associated mostly with the 0.005 M DTPA and 0.1 M EDTA extractable fractions, while $\mathrm{Ni}$ was associated with the $0.1 \mathrm{M} \mathrm{HCl}$ and $1 \mathrm{M} \mathrm{HCl}$ fractions in most cases. The fractions of metals extracted using the sequential extraction procedure varied compared to single extractions for all soil types.
\end{abstract}

\section{Introduction}

Heavy metal contamination of the soils of Bangladesh has not yet reached a level for concern $^{(1)}$. However, heavy metal contamination of arable soils through industrial activities is likely to reach alarming levels in the near future. Industrial waste has been found to increase the heavy metal load in surrounding agricultural soils(2). These metals are taken up by plants and from there enter into the food chain where they may cause health hazards ${ }^{(3)}$.

Chemical extraction procedures enable the prediction of changes in heavy metal mobility or bioavailability in soils(4). In order to understand the chemistry of heavy metals in their interactions with other soil components, such as clay minerals, organic matter and the soil solution, or to assess their mobility and retention as well as their availability to plants, the usual approach is to use selective chemical extraction(5). Single and sequential extraction methods have been used in the study of nutrient element

\footnotetext{
*Author for correspondence: <imamhuq@hotmail.com>.
} 
deficiency in agricultural crops and animals as well as in environmental pollution analysis ${ }^{(1,4)}$. The ultimate goal of such studies has been to see whether different pools of elements in soil are obtained using different extractants, both in single and sequential extraction. These properties could be linked to phytoavailability, phytoremediation and/or soil reclamation. However, data on plant uptake and the pool of elements extracted using different extractants are lacking. The present study aims at assessing the phytoavailability of heavy metals in soils varying in their degree of contamination and using various extraction procedures.

\section{Materials and Methods}

Three surface soils $(0-150 \mathrm{~mm})$, two from sites suspected to be contaminated and one from a site with no known source of industrial contamination were used. The suspected contaminated soils (steel mill and textile mill soils) were collected from the

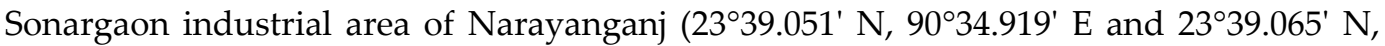
$\left.90^{\circ} 34.903^{\prime} \mathrm{E}\right)$ and the apparently non-contaminated soil was collected from an agricultural land located in Dhamrai, Dhaka (23⒌749' N, 90 $10.842^{\prime}$ E). A sample of artificially spiked (as described below) Dhamrai soil was also included in the study. The soils were designated NC (apparently non-contaminated, Dhamrai series), SM (steel mill soil, Sonatala series), TM (textile mill soil, Shilmandi series) and Sp (spiked soil, Dhamrai series). The collected soil samples were processed following the procedures described by Imamul Huq and Alam(6).

In order to study the phytoavailability of heavy metals in soil and their extractability by different extractants, a pot culture experiment was set up with the soils of NC, SM, TM and Sp. Two crop species were used: An upland crop, Ipomoea aquatica, which is a leafy-vegetable plant commonly known as "Kalmi Sak"; and a lowland crop, rice (Oryza sativa L.; BRRI dhan-29). Upland and submerged conditions were maintained for growing Kalmi and rice, respectively. All experiments were performed in triplicate, as follows:

- 12 pots $(2 \times 2 \times 3)$ for the two suspected contaminated soils (each soil with two plant species);

- 6 pots $(2 \times 3)$ for the non-contaminated soil (with two plant species), representing the control; and 6 pots $(2 \times 3)$ containing the spiked soils (with two plant species).

Earthen pots $(5 \mathrm{~kg}$ and $7 \mathrm{~kg}$ ) with no hole at the bottom were used. Air-dried $5 \mathrm{~mm}$ sieved soil samples amounting to $4 \mathrm{~kg}$ and $5 \mathrm{~kg}$ were placed in each of the earthen pots to grow Ipomoea and rice, respectively.

For spiking, solutions of $\mathrm{Cu}$ and $\mathrm{Ni}$ (as $\mathrm{CuSO}_{4} \cdot 5 \mathrm{H}_{2} \mathrm{O}$ and $\mathrm{NiSO}_{4}$ ), at concentrations one and a half times that of the standard background levels of the corresponding metals in the Dhamrai soil were used (Table 1). The metal salts used were $\mathrm{CuSO}_{4} \cdot 5 \mathrm{H}_{2} \mathrm{O}$ and 
$\mathrm{NiSO}_{4}$. Solutions were made separately using $300 \mathrm{ml}$ distilled water and mixed uniformly with the soils adding $100 \mathrm{ml}$ of each to the pots. The spiked pots were allowed to stand for two weeks before plantation. The same spiking procedure was used for an additional pot that was used to measure the amount of the elements two weeks after spiking. This measure was the background value for the spiked soils.

Table 1. Spiking rates of the heavy metals.

\begin{tabular}{lcc}
\hline Element & Standard background value* $(\mathrm{mg} / \mathrm{kg})$ & Spiking rate $(\mathrm{mg} / \mathrm{kg})$ \\
\hline Copper $(\mathrm{Cu})$ & 26 & 39 \\
Nickel $(\mathrm{Ni})$ & 20 & 30 \\
\hline
\end{tabular}

*Source: Imamul Huq and Alam(6).

Ipomoea seeds were obtained from a local market and rice seedlings (BRRI dhan-29) were collected from a farmer's field. Ten Ipomoea seeds were sown in each pot. After 12 days the seeds began to germinate and 5 seedlings/pot were allowed to grow. For rice, soil was puddled and 9 rice seedlings/pot were randomly transplanted and allowed to grow. All pots were placed in a net-house in a randomized arrangement. Plants were watered with tap water as and when required. A blanket application of urea $\mathrm{N}$ was made after transplantation of seedlings. Positions of the pots were changed every alternate day to allow equal exposure of each pot to sunlight. Adequate plant protection measures were taken and the appearances of any symptoms were noted during the growing period.

At harvest, the plants and soils were collected individually for chemical analysis. Ipomoea plants were harvested manually by uprooting them carefully after 45 days of emergence and were prepared for analysis( ${ }^{(6)}$. The plant samples were separated into roots and edible parts (shoots and leaves). Rice plants were harvested 110 days after transplantation. Fresh and dry weights of roots and shoots of the plants together with the weights of 1000 grains were recorded.

The properties of the soil samples were analyzed in the laboratory ${ }^{(6)}$. The background concentrations of total $\mathrm{Cu}$ and $\mathrm{Ni}$ (pre- and post-experiment) of the soils were determined by digestion of the soils using aqua regia. The total concentrations of the metals in the plants and soils were measured by flame-atomic absorption spectrometer (Varian-Spectra 220). The quality control/quality assurance (QC/QA) of the analyses was as described by Imamul Huq et al.(7).

The various extractants used are presented in the Table 2. Soils were both singly and sequentially extracted. Extraction of all four soil types with each of the extractants was performed in triplicate. Required amounts of the extractants were prepared and the specific ratios of soil to extractant were according those listed in Table 2. For the 
sequential extraction procedure (SEP), $10 \mathrm{~g}$ soil ( $2 \mathrm{~mm}$ sieved fraction) was placed in a $50 \mathrm{ml}$ polycarbonate centrifuge tube and the extractions were performed sequentially in the order of strength of the extractants (distilled $\mathrm{H}_{2} \mathrm{O}<1 \mathrm{M} \mathrm{NH}_{4} \mathrm{Cl}<0.01 \mathrm{M} \mathrm{CaCl}_{2}<0.005$ M DTPA (diethylenetriamine pentaacetic acid) $<0.1 \mathrm{M}$ EDTA (ethylenediamine tetraacetic acid) $<0.1 \mathrm{M} \mathrm{HCl}<1 \mathrm{M} \mathrm{HCl}$ ) at a ratio of $1: 2$ and following the duration given in the Table 2. Extractions were performed in triplicate for each sample. All the extracts were centrifuged for 5 minutes at $2000 \mathrm{rpm}$ and the supernatants were collected.

Table 2. Extraction methods used in the study.

\begin{tabular}{|c|c|c|c|}
\hline Extractant & $\begin{array}{l}\text { Ratio }(\mathrm{w} / \mathrm{v}) / \\
\text { time/temperature }\end{array}$ & Pool & Reference \\
\hline Distilled $\mathrm{H}_{2} \mathrm{O}$ & $1: 10,1 \mathrm{~h}$, room temp. & Water soluble & - \\
\hline $1 \mathrm{M} \mathrm{NH}_{4} \mathrm{Cl}$ & $1: 6,16 \mathrm{~h} \quad "$ & $\begin{array}{l}\text { Neutral salt } \\
\text { soluble/exchangeable }\end{array}$ & Krishnamurti et al. ${ }^{(8)}$ \\
\hline $0.01 \mathrm{M} \mathrm{CaCl}_{2}$ & $1: 5,16 \mathrm{~h} \quad "$ & $\begin{array}{l}\text { Neutral salt soluble/ } \\
\text { exchangeable }\end{array}$ & Ahnstrom and Parker ${ }^{(9)}$ \\
\hline 0.005 M DTPA & $1: 2,2 \mathrm{~h}$ & Chelating extractable & Lindsay and Norvell(10) \\
\hline $0.1 \mathrm{M}$ EDTA & $1: 2,2 \mathrm{~h}$ & Chelating extractable & Lindsay and Norvell(10) \\
\hline $0.1 \mathrm{M} \mathrm{HCl}$ & $1: 10,0.5 \mathrm{~h} "$ & Weak acid extractable & $\operatorname{CSTPA}^{(11)}$ \\
\hline $1 \mathrm{M} \mathrm{HCl}$ & $1: 33.3,2 \mathrm{~h} "$ & Weak acid extractable & ANZECC and ARMCANZ \\
\hline
\end{tabular}

The data were statistically evaluated using Pearson correlation coefficients and descriptive statistics were performed using Sigma Plot (v.12.0) and Minitab (v.16, Minitab, Inc.).

\section{Results and Discussion}

The selected soils were analyzed to ascertain the levels of $\mathrm{Cu}$ and $\mathrm{Ni}$ in them. The total $\mathrm{Cu}$ values were $63.93,35.59,26.24$ and $139.23 \mathrm{mg} / \mathrm{Kg}$ in the $\mathrm{NC}, \mathrm{SM}, \mathrm{TM}$ and Sp soils, respectively while the total $\mathrm{Ni}$ values were $115.34,98.68,57.59$ and $183.62 \mathrm{mg} / \mathrm{Kg}$ in NC, SM, TM and Sp soils respectively. Soil pH ranged from 4.4 to 5.8 in the contaminated soils. These lower $\mathrm{pH}$ values may be attributed to acid effluent coming from nearby industrial operations as well as high organic content.

Among the seven extractants used, $1 \mathrm{M} \mathrm{HCl}$ extracted the highest proportion of $\mathrm{Cu}$ $(28.68-50.30 \%)$ and $\mathrm{Ni}(6.77-50.54 \%)$ from the soils (Tables 3a and 3b). Regardless of the soils and extractants, the relative metal extractability was observed to be in the order: $\mathrm{Cu}$ $>$ Ni. Evidently, $1 \mathrm{M} \mathrm{HCl}$ was the most efficient agent for extracting $\mathrm{Cu}$ (av. for all soils $41 \%$ ), followed by Ni (av. for all soils $28 \%$ ) from the soils. There was a wide difference in metal extractability between $0.1 \mathrm{M} \mathrm{HCl}$ and $1 \mathrm{M} \mathrm{HCl}$ extractants. The amount of $\mathrm{Ni}$ extracted by $\mathrm{H}_{2} \mathrm{O}$ in the suspected contaminated soils (SM and TM) varied from 3.05 to $5.4 \%$, whereas the $\mathrm{H}_{2} \mathrm{O}$ extractable fractions of $\mathrm{Cu}$ in the soils were below the detection 
Table 3a. Levels (mg/kg) and per cent of total (in parentheses) $\mathrm{Cu}$ in the soils after individual extractions.

\begin{tabular}{|c|c|c|c|c|c|}
\hline Soil & Extractants & $\begin{array}{l}\text { Range } \\
\text { (Min. to max.) }\end{array}$ & $\mathrm{Sd}$ & $\begin{array}{l}\text { \% of Total } \\
\text { (Min. to max.) }\end{array}$ & Mean (\%) \\
\hline \multirow{8}{*}{$\mathrm{NC}$} & Distilled $\mathrm{H}_{2} \mathrm{O}$ & BDL & BDL & BDL & BDL \\
\hline & $1 \mathrm{M} \mathrm{NH}_{4} \mathrm{Cl}$ & $0.24-0.54$ & \pm 0.15 & $0.38-0.84$ & $0.38(0.59)$ \\
\hline & $0.01 \mathrm{M} \mathrm{CaCl}_{2}$ & $0.085-0.09$ & \pm 0.003 & $0.13-0.14$ & $0.088(0.14)$ \\
\hline & DTPA & $2.97-3.27$ & \pm 0.17 & $4.65-5.12$ & $3.17(4.96)$ \\
\hline & $0.1 \mathrm{M}$ EDTA & $8.05-8.40$ & \pm 0.17 & $12.59-13.13$ & $8.23(12.87)$ \\
\hline & $0.1 \mathrm{M} \mathrm{HCl}$ & $9.73-12.38$ & \pm 1.37 & $15.22-19.36$ & $10.86(16.99)$ \\
\hline & $1 \mathrm{M} \mathrm{HCl}$ & $18.33-19.33$ & \pm 0.50 & $28.68-30.24$ & $18.84(29.48)$ \\
\hline & Boiled aqua regia & $61.73-66.06$ & \pm 2.17 & - & 63.93 \\
\hline \multirow{8}{*}{ SM } & Distilled $\mathrm{H}_{2} \mathrm{O}$ & BDL & BDL & BDL & BDL \\
\hline & $1 \mathrm{M} \mathrm{NH}_{4} \mathrm{Cl}$ & $0.01-0.53$ & \pm 0.30 & $0.02-1.48$ & $0.19(0.52)$ \\
\hline & $0.01 \mathrm{M} \mathrm{CaCl}_{2}$ & $0.10-0.15$ & \pm 0.03 & $0.27-0.41$ & $0.12(0.32)$ \\
\hline & DTPA & $5.68-8.70$ & \pm 1.51 & $15.96-24.46$ & 7.17 (20.14) \\
\hline & 0.1 M EDTA & $10.03-10.10$ & \pm 0.04 & $28.20-28.38$ & $10.06(28.26)$ \\
\hline & $0.1 \mathrm{M} \mathrm{HCl}$ & $10.61-18.80$ & \pm 4.67 & $29.81-52.83$ & $13.41(37.67)$ \\
\hline & $1 \mathrm{M} \mathrm{HCl}$ & $16.93-17.90$ & \pm 0.52 & $47.58-50.30$ & $17.52(49.24)$ \\
\hline & Boiled aqua regia & $34.96-36.56$ & \pm 0.85 & - & 35.59 \\
\hline \multirow{8}{*}{$\mathrm{TM}$} & Distilled $\mathrm{H}_{2} \mathrm{O}$ & BDL & BDL & BDL & BDL \\
\hline & $1 \mathrm{M} \mathrm{NH}_{4} \mathrm{Cl}$ & $0.01-0.02$ & \pm 0.01 & $0.02-0.07$ & $0.01(0.05)$ \\
\hline & $0.01 \mathrm{M} \mathrm{CaCl}_{2}$ & $0.14-0.18$ & \pm 0.02 & $0.53-0.69$ & $0.16(0.60)$ \\
\hline & DTPA & $3.50-3.68$ & \pm 0.09 & $13.35-14.01$ & 3.57 (13.61) \\
\hline & 0.1 M EDTA & $6.62-7.16$ & \pm 0.27 & $25.22-27.29$ & $6.87(26.19)$ \\
\hline & $0.1 \mathrm{M} \mathrm{HCl}$ & $6.93-9.20$ & \pm 1.29 & $26.41-35.07$ & 7.71 (29.37) \\
\hline & $1 \mathrm{M} \mathrm{HCl}$ & $9.73-10.50$ & \pm 0.39 & $37.10-40.02$ & $10.17(38.75)$ \\
\hline & Boiled aqua regia & $25.90-26.84$ & \pm 0.52 & - & 26.24 \\
\hline \multirow{8}{*}{ Sp } & Distilled $\mathrm{H}_{2} \mathrm{O}$ & BDL & BDL & BDL & BDL \\
\hline & $1 \mathrm{M} \mathrm{NH}_{4} \mathrm{Cl}$ & $0.01-0.58$ & \pm 0.30 & $0.004-0.42$ & $0.34(0.25)$ \\
\hline & $0.01 \mathrm{M} \mathrm{CaCl}_{2}$ & $0.12-0.16$ & \pm 0.02 & $0.09-0.11$ & $0.14(0.10)$ \\
\hline & DTPA & $13.54-14.37$ & \pm 0.42 & $9.72-10.32$ & $13.96(10.03)$ \\
\hline & $0.1 \mathrm{M}$ EDTA & $29.16-29.28$ & \pm 0.06 & $20.94-21.03$ & 29.22 (20.99) \\
\hline & $0.1 \mathrm{M} \mathrm{HCl}$ & $43.94-55.92$ & \pm 6.63 & $31.56-40.16$ & $51.57(37.04)$ \\
\hline & $1 \mathrm{M} \mathrm{HCl}$ & $65.07-67.20$ & \pm 1.20 & $46.73-48.27$ & $65.81(47.27)$ \\
\hline & Boiled aqua regia & $126.51-160.33$ & \pm 18.40 & - & 139.23 \\
\hline
\end{tabular}

$\mathrm{Sd}=$ Standard division, $\mathrm{BDL}=$ Below detection limit. 
Table $3 \mathrm{~b}$. Levels $(\mathrm{mg} / \mathrm{kg}$ ) and per cent of total (in parentheses) $\mathrm{Ni}$ in the soils after individual extractions.

\begin{tabular}{|c|c|c|c|c|c|}
\hline Soil & Extractants & $\begin{array}{l}\text { Range } \\
\text { (Min. to max.) }\end{array}$ & $\mathrm{SD}$ & $\begin{array}{l}\text { \% of total } \\
\text { (Min. to max.) }\end{array}$ & Mean (\%) \\
\hline \multirow{7}{*}{$\mathrm{NC}$} & Distilled $\mathrm{H}_{2} \mathrm{O}$ & $2.96-3.26$ & \pm 0.16 & $2.41-2.65$ & $3.15(2.56)$ \\
\hline & $1 \mathrm{M} \mathrm{NH}_{4} \mathrm{Cl}$ & $0.32-2.36$ & \pm 1.11 & $0.26-1.92$ & $1.08(0.88)$ \\
\hline & $0.01 \mathrm{M} \mathrm{CaCl}_{2}$ & $1.79-1.99$ & \pm 0.11 & $1.45-1.62$ & $1.86(1.52)$ \\
\hline & DTPA & $0.56-0.60$ & \pm 0.02 & $0.46-0.49$ & $0.58(0.47)$ \\
\hline & $0.1 \mathrm{M}$ EDTA & $2.30-2.44$ & \pm 0.07 & $1.87-1.99$ & $2.38(1.93)$ \\
\hline & $0.1 \mathrm{M} \mathrm{HCl}$ & $5.29-6.59$ & \pm 0.66 & $4.31-5.36$ & $5.89(4.79)$ \\
\hline & $1 \mathrm{M} \mathrm{HCl}$ & $20.90-21.30$ & \pm 0.22 & $17.01-17.34$ & $21.04(17.13)$ \\
\hline \multirow{9}{*}{$\mathrm{SM}$} & Boiled aqua regia & $119.54-125.47$ & \pm 3.02 & - & 122.85 \\
\hline & Distilled $\mathrm{H}_{2} \mathrm{O}$ & $3.37-3.70$ & \pm 0.17 & $2.92-3.21$ & $3.52(3.05)$ \\
\hline & $1 \mathrm{M} \mathrm{NH}_{4} \mathrm{Cl}$ & $5.89-6.76$ & \pm 0.45 & $5.11-5.86$ & $6.39(5.54)$ \\
\hline & $0.01 \mathrm{M} \mathrm{CaCl}_{2}$ & $4.35-5.36$ & \pm 0.51 & $3.77-4.64$ & $4.89(4.24)$ \\
\hline & DTPA & $4.23-4.28$ & \pm 0.03 & $3.67-3.71$ & $4.25(3.68)$ \\
\hline & $0.1 \mathrm{M}$ EDTA & $4.92-5.11$ & \pm 0.10 & $4.26-4.43$ & $5.03(4.36)$ \\
\hline & $0.1 \mathrm{M} \mathrm{HCl}$ & $5.90-11.64$ & \pm 0.94 & $5.12-10.09$ & $8.32(7.21)$ \\
\hline & $1 \mathrm{M} \mathrm{HCl}$ & $56.80-58.30$ & \pm 0.75 & $49.24-50.54$ & $57.54(49.89)$ \\
\hline & Boiled aqua regia & 112.57 - 117.02 & \pm 2.42 & - & 115.34 \\
\hline \multirow{8}{*}{$\mathrm{TM}$} & Distilled $\mathrm{H}_{2} \mathrm{O}$ & $2.86-3.26$ & \pm 0.22 & $4.97-5.66$ & $3.11(5.40)$ \\
\hline & $1 \mathrm{M} \mathrm{NH}_{4} \mathrm{Cl}$ & $2.72-3.15$ & \pm 0.22 & $4.73-5.47$ & $2.92(5.07)$ \\
\hline & $0.01 \mathrm{M} \mathrm{CaCl}_{2}$ & $2.00-2.15$ & \pm 0.07 & $3.47-3.72$ & $2.07(3.59)$ \\
\hline & DTPA & $1.36-1.52$ & \pm 0.09 & $2.37-2.65$ & $1.42(2.46)$ \\
\hline & 0.1 M EDTA & $2.52-2.72$ & \pm 0.11 & $4.38-4.72$ & $2.60(4.51)$ \\
\hline & $0.1 \mathrm{M} \mathrm{HCl}$ & $4.53-6.20$ & \pm 0.94 & $7.87-10.77$ & $5.12(8.89)$ \\
\hline & $1 \mathrm{M} \mathrm{HCl}$ & $21.77-24.03$ & \pm 1.14 & $37.79-41.73$ & $22.82(39.63)$ \\
\hline & Boiled aqua regia & $54.70-61.63$ & \pm 3.60 & - & 57.59 \\
\hline \multirow{8}{*}{ Sp } & Distilled $\mathrm{H}_{2} \mathrm{O}$ & $3.23-3.76$ & \pm 0.30 & $1.76-2.05$ & $3.42(1.86)$ \\
\hline & $1 \mathrm{M} \mathrm{NH}_{4} \mathrm{Cl}$ & $4.66-6.92$ & \pm 1.15 & $2.54-3.77$ & $5.65(3.08)$ \\
\hline & $0.01 \mathrm{M} \mathrm{CaCl}_{2}$ & $1.99-2.10$ & \pm 0.06 & $1.08-1.14$ & $2.03(1.11)$ \\
\hline & DTPA & $2.25-2.57$ & \pm 0.16 & $1.22-1.40$ & $2.41(1.31)$ \\
\hline & $0.1 \mathrm{M}$ EDTA & $13.87-15.75$ & \pm 1.00 & $7.55-8.58$ & $14.61(7.96)$ \\
\hline & $0.1 \mathrm{M} \mathrm{HCl}$ & $5.90-11.64$ & \pm 2.98 & $3.21-6.34$ & $8.32(4.53)$ \\
\hline & $1 \mathrm{M} \mathrm{HCl}$ & $12.43-13.87$ & \pm 0.78 & $6.77-7.55$ & $12.97(7.06)$ \\
\hline & Boiled aqua regia & $176.78-195.87$ & \pm 10.63 & - & 183.62 \\
\hline
\end{tabular}

$\mathrm{Sd}=$ Standard division 
limit. $\mathrm{CaCl}_{2}$ extracted a relatively smaller amounts $(0.1-0.7 \% \mathrm{Cu}, 1.1-4.6 \%)$ of total $\mathrm{Cu}$ and $\mathrm{Ni}$ than $\mathrm{NH}_{4} \mathrm{Cl}(0.004-1.5 \% \mathrm{Cu}, 0.3-6 \% \mathrm{Ni})$ from the soils. The chloride salts $\left(\mathrm{NH}_{4} \mathrm{Cl}\right.$ and $\left.\mathrm{CaCl}_{2}\right)$ were found to be weak extractants for $\mathrm{Cu}$ (up to 1.5\%). EDTA was a better extractant than DTPA for the metals. DTPA extracts metals that are thought to represent the plant-available fractions ${ }^{(4,10,13)}$. DTPA and EDTA form soluble complexes with metals, reducing their activity in the soil solution; therefore, ions desorbed from the surface enter into the extraction solution ${ }^{(1)}$. It is clear that $\mathrm{HCl}$ is a better extractant for the metals though the $1 \mathrm{M}$ concentration performed better than the $0.1 \mathrm{M} \mathrm{HCl}$. The extractability, in general, of the metals with different extractants was in the order: $1 \mathrm{M}$ $\mathrm{HCl}>0.1 \mathrm{M} \mathrm{HCl}>0.1 \mathrm{M}$ EDTA $>$ DTPA $>1 \mathrm{M} \mathrm{NH}_{4} \mathrm{Cl}>0.01 \mathrm{M} \mathrm{CaCl}_{2}>\mathrm{H}_{2} \mathrm{O}$. It is, therefore, apparent from these results that $1 \mathrm{M} \mathrm{HCl}$ is the best choice for $\mathrm{Cu}$ and $\mathrm{Ni}$ extraction from soil.

The extent of contamination due to heavy metal deposition in the NC, SM, TM and Sp soils was identified by using information of background levels of the metal elements for Bangladesh soils(14) and the tolerable and in excess of tolerable level was calculated on the information of Kloke ${ }^{(15)}$. Background concentrations for $\mathrm{Cu}$ and $\mathrm{Ni}$ of Bangladesh soils were 27 and $22 \mathrm{mg} / \mathrm{kg}$, respectively, whereas the maximum tolerable concentrations were defined as 100 and $50 \mathrm{mg} / \mathrm{kg}$ for $\mathrm{Cu}$ and $\mathrm{Ni}$, respectively. The total heavy metal contents of the soil samples (Table 4) showed a wide variation in values ranging from levels similar to background to a level reflective of severe contamination. The levels of $\mathrm{Cu}$ in all the soils were within the tolerable limit $(>27-\leq 100 \mathrm{mg} / \mathrm{kg}$ ), whereas $\mathrm{Ni}$ concentration in the soils were found to be in excess of tolerable level ( $\geq 50 \mathrm{mg} / \mathrm{kg}$ ) with the exception of the TM soil, which had a total Ni concentration of $57.6 \mathrm{mg} / \mathrm{kg}$, which is within the tolerable level.

The apparently non-contaminated soil (NC) contained relatively higher amounts of $\mathrm{Cu}$ and $\mathrm{Ni}$ than the suspected contaminated soils (SM or TM soils). The higher values for the elements in the NC soil were perhaps due to the sampling site of the Dhamrai soil being adjacent to the Dhaka-Manikganj highway. Levels of some heavy metals have previously been reported to be high in soils along the highways due to automobile exhaust $^{(16)}$. However, of the two industrial sites in this study, higher contents of the metals were found in the soils of the steel mill area. The heavy metals found in soils make the plants and soil biota living there vulnerable to metal toxicity. The extent of contamination was observed to be higher in the steel mill area than in the textile mill area and this might be due to an excessive amount of heavy metals in the discharged effluents.

Evidently, $1 \mathrm{M} \mathrm{HCl}$ was the most efficient agent for extracting $\mathrm{Cu}(41.2 \%)$ and $\mathrm{Ni}$ $(28.4 \%)$ from the soils. This indicates that $1 \mathrm{M} \mathrm{HCl}$ extracted most of the non-residual fraction of the metal elements. The sequential extraction procedure (SEP) showed that $\mathrm{Cu}$ and $\mathrm{Ni}$ were associated mostly with the DTPA and $1 \mathrm{M} \mathrm{HCl}$ extractable fractions, 
respectively. Copper was also associated with the EDTA, $0.1 \mathrm{M} \mathrm{HCl}$ and $1 \mathrm{M} \mathrm{HCl}$ fractions (Figs 1 and 2). Water, $\mathrm{NH}_{4} \mathrm{Cl}$ and $\mathrm{CaCl}_{2}$ were very poor extractants, as observed in the SEP data. It is apparent that the fractions of the metals extracted from the soils using the SEP varied widely compared to the single extractions. Chowdhury et al.(1) observed similar variations for cadmium, lead and zinc in the same soils.

Dry matter produced for Ipomoea and rice was better in the SM and TM soils than in the NC and Sp soils. The mean dry weights of different parts of Ipomoea and rice along with 1000 grain weight of rice grown in the soils are presented in the Table 4.

Table 4. Dry weights of plant tissue of Ipomoea aquatica and rice.

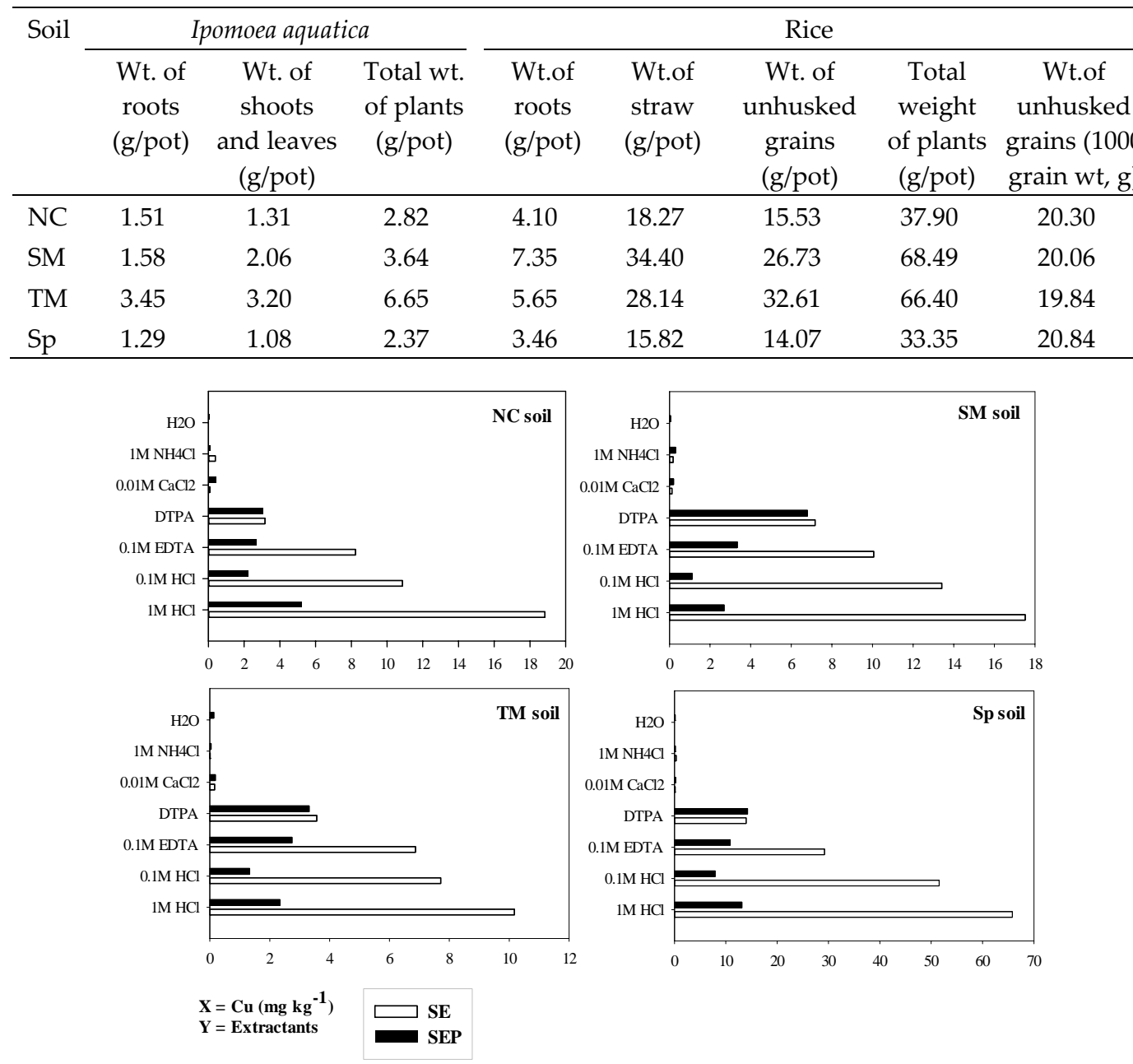

Fig. 1. Mean proportion of $\mathrm{Cu}$ in each of the single extractants (SE) compared with the corresponding fraction in the sequential extraction procedure (SEP) for NC, SM, TM and Sp soils. 
The maximum concentration of $\mathrm{Cu}$ and $\mathrm{Ni}(51.4$ and $33.2 \mathrm{mg} / \mathrm{kg}$ ) were observed in the edible parts of Ipomoea (shoots + leaves) grown in the SM soil, while in the rice grains, the metal concentrations (11.9 and $13 \mathrm{mg} / \mathrm{kg}$, respectively, for $\mathrm{Cu}$ and $\mathrm{Ni}$ ) were found to be the highest in the Sp soil (Table 5). Copper and Ni contents were found to be much higher in the edible parts of Ipomoea than in the rice grains (Fig. 3).

According to Kabata-Pendias ${ }^{(17)}$, the normal levels of $\mathrm{Cu}$ and $\mathrm{Ni}$ in mature leaf tissue vary from $5-30$ and $0.1-5 \mathrm{mg} / \mathrm{kg}$, respectively and the toxic levels of the same metals range from $20-100$ and $10-100 \mathrm{mg} / \mathrm{kg}$, respectively. The tolerable concentrations of $\mathrm{Cu}$ and $\mathrm{Ni}$ in agronomic crops range from $5-20$ and $1-10 \mathrm{mg} / \mathrm{kg}$, respectively. In the present study, the total contents of $\mathrm{Cu}$ in Ipomoea $(74.7-120.8 \mathrm{mg} / \mathrm{kg})$ and rice plants $(107$ - $256.5 \mathrm{mg} / \mathrm{kg}$ ) grown in the soils were much higher than the toxic level. The concentration of $\mathrm{Cu}$ in rice grains $(6.3-11.9 \mathrm{mg} / \mathrm{kg})$ was found within the tolerable limit, whereas in the edible parts of Ipomoea the concentration $(30.7-51.4 \mathrm{mg} / \mathrm{kg}$ ) exceeded the toxic limit. The total concentration of $\mathrm{Ni}$ in Ipomoea $(55-73.2 \mathrm{mg} / \mathrm{kg}$ ) was within the toxic limit exceeding the normal and tolerable limits, while in the rice plants the concentration (116.1 - $151 \mathrm{mg} / \mathrm{kg}$ ) was found to be much higher than the toxic level. In all the soils, the concentrations of $\mathrm{Ni}$ in the edible parts of both the plant species $(10.9-13 \mathrm{mg} / \mathrm{kg}$ in rice and $20.9-33.2 \mathrm{mg} / \mathrm{kg}$ in Ipomoea) were found to be within the toxic range.
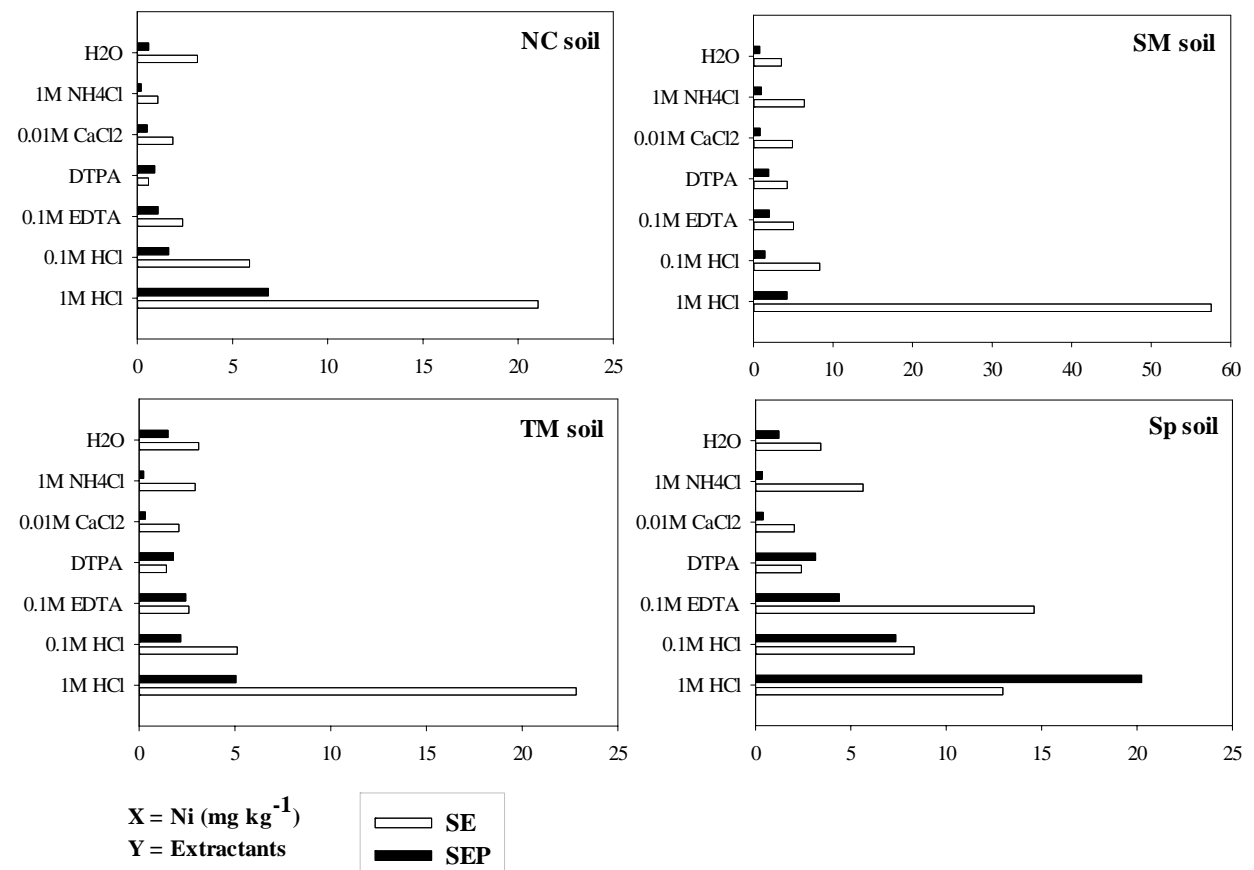

Fig. 2. Mean proportion of $\mathrm{Ni}$ in each of the single extractants (SE) compared with the corresponding fraction in the sequential extraction procedure (SEP) for NC, SM, TM and Sp soils. 
However, the concentrations of the metal elements in the plants were found much higher in the steel mill soil than the soil in textile mill area. This may be due to the fact that the metals were in a more labile state than those in the TM soil. The TM soil would have been contaminated primarily with cellulosic organic waste, with the metals bound to these organic materials rendering them less mobile for plant uptake. Elevated levels of $\mathrm{Cu}$ and $\mathrm{Ni}$ in plants near metal smelters have previously been demonstrated in other investigations ${ }^{(18-21)}$.

Table 5. Levels $(\mathrm{mg} / \mathrm{kg})$ of $\mathrm{Cu}$ and $\mathrm{Ni}$ in Ipomoea and rice.

\begin{tabular}{|c|c|c|c|c|c|c|c|c|c|c|}
\hline \multirow[b]{2}{*}{ Metal } & \multirow[b]{2}{*}{ Soil } & \multicolumn{3}{|c|}{ Ipomoea } & \multicolumn{6}{|c|}{ Rice } \\
\hline & & Root & $\begin{array}{c}\text { Shoot }+ \\
\text { leaf }\end{array}$ & Total & Root & Straw & Grain & Husk & $\begin{array}{c}\text { Grain + } \\
\text { husk }\end{array}$ & Total \\
\hline \multirow{4}{*}{$\mathrm{Cu}$} & $\mathrm{NC}$ & 43.4 & 31.3 & 74.7 & 55.6 & 32.3 & 9.0 & 10.1 & 19.1 & 107.0 \\
\hline & $\mathrm{SM}$ & 69.4 & 51.4 & 120.8 & 87.4 & 39.2 & 9.1 & 12.5 & 21.6 & 148.1 \\
\hline & $\mathrm{TM}$ & 78.6 & 30.7 & 109.3 & 63.8 & 30.9 & 6.3 & 7.9 & 14.2 & 108.9 \\
\hline & Sp & 81.6 & 34.2 & 115.8 & 189.1 & 42.2 & 11.9 & 13.3 & 25.2 & 256.5 \\
\hline \multirow{4}{*}{$\mathrm{Ni}$} & $\mathrm{NC}$ & 33.7 & 29.6 & 63.3 & 58.0 & 17.9 & 12.8 & 27.4 & 40.2 & 116.1 \\
\hline & $\mathrm{SM}$ & 40.0 & 33.2 & 73.2 & 70.8 & 25.9 & 11.5 & 30.7 & 42.2 & 138.9 \\
\hline & $\mathrm{TM}$ & 34.2 & 20.9 & 55.0 & 62.6 & 23.1 & 10.9 & 22.6 & 33.5 & 119.2 \\
\hline & $S p$ & 40.7 & 28.2 & 68.9 & 87.2 & 27.4 & 13.0 & 23.4 & 36.4 & 151.0 \\
\hline
\end{tabular}
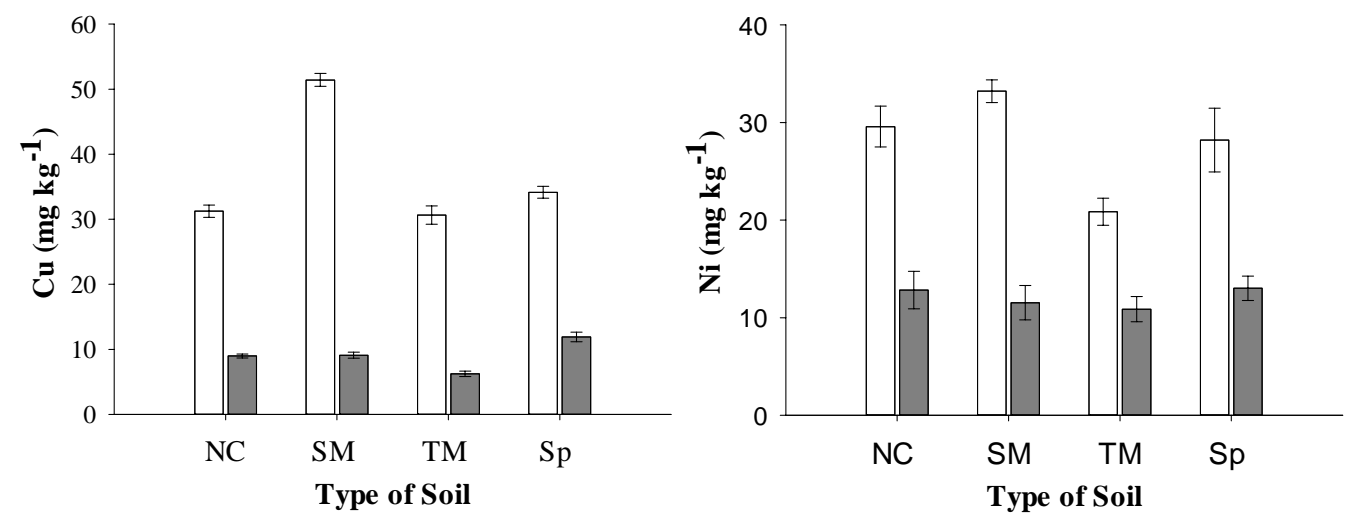

$$
\begin{aligned}
& \longleftarrow \text { Ipomoea } \text { shoot }+ \text { leaf } \\
& \text { Rice grain }
\end{aligned}
$$

Fig. 3. Comparison of $\mathrm{Cu}$ and $\mathrm{Ni}$ in the edible parts of Ipomoea and rice.

The maximum uptake of $\mathrm{Cu}$ in Ipomoea was found for the TM soil $(0.37 \mathrm{mg} / \mathrm{pot})$, with $73 \%$ in the roots and $27 \%$ in the edible parts. The highest $\mathrm{Cu}$ levels in rice plants were found in the SM soil $(2.6 \mathrm{mg} / \mathrm{pot})$, with the major portion taken up by rice straw (up to $53 \%$ of total uptake) in all soil types (Fig. 4). In the edible parts of rice (husk + grains), the 
maximum uptake of $\mathrm{Cu}$ was observed for the SM soil (0.58 mg/pot), followed by the TM, Sp and NC soils.

The maximum uptake of $\mathrm{Ni}$ by Ipomoea was observed in the TM soil $(0.18 \mathrm{mg} / \mathrm{pot})$, followed by the SM $(0.13 \mathrm{mg} / \mathrm{pot}), \mathrm{NC}(0.09 \mathrm{mg} / \mathrm{pot})$ and Sp $(0.08 \mathrm{mg} / \mathrm{pot})$ soils. The maximum uptake of $\mathrm{Ni}$ by the roots of Ipomoea was found in the TM soil $(0.12 \mathrm{mg} / \mathrm{pot})$ and by the edible parts in both the SM and TM soils $(0.07 \mathrm{mg} / \mathrm{pot})$ (Fig. 4). These values represented $65.5 \%$ (by roots) and $37.1 \%$ (by shoots and leaves) of the total $\mathrm{Cu}$ accumulation in Ipomoea. The level of Ni uptake by rice plants was in the order: SM soil > TM soil > Sp soil > NC soil (Fig. 4). The uptake of Ni in the edible parts of rice (husk + grains) was found to be the highest in the SM soil $(1.13 \mathrm{mg} /$ pot; $44.4 \%$ of the total uptake) and the quantity in the TM soil was $1.1 \mathrm{mg} /$ pot (52.1\% of the total uptake).

Ipomoea aquatica $\mathrm{L}$.

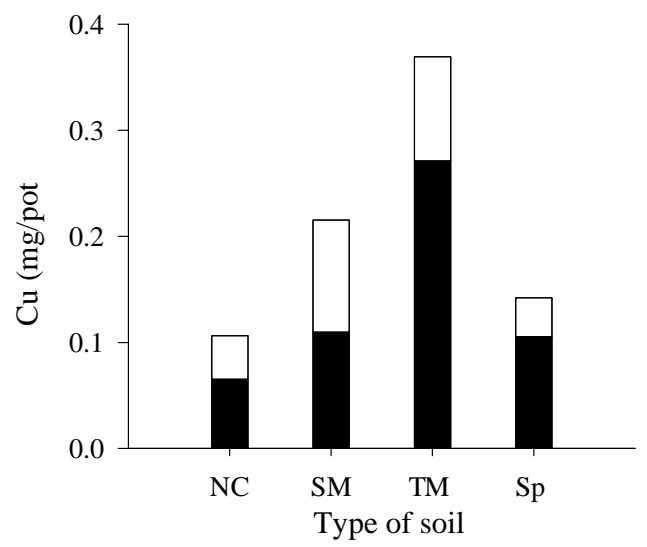

Rice (Oryza sativa L.

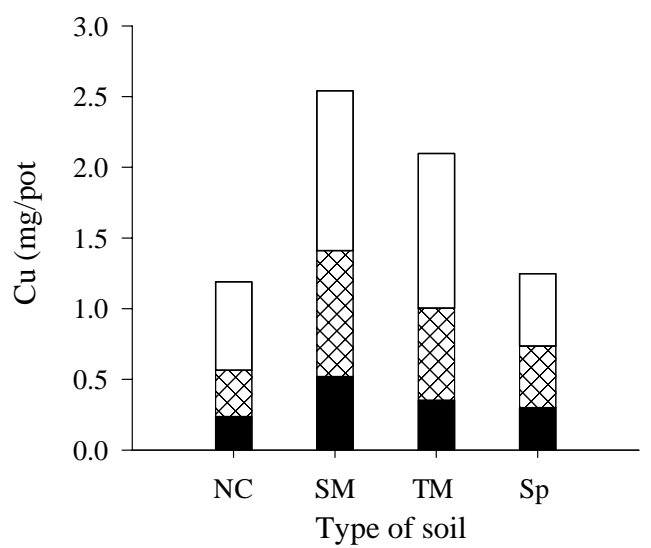

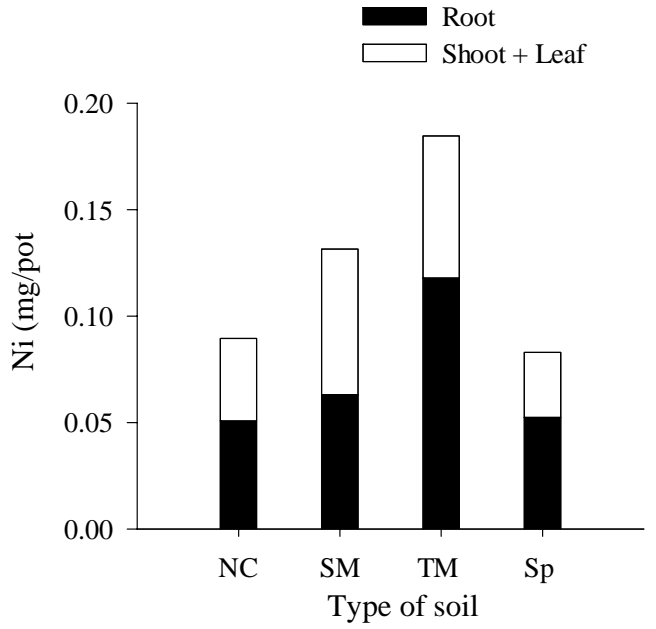

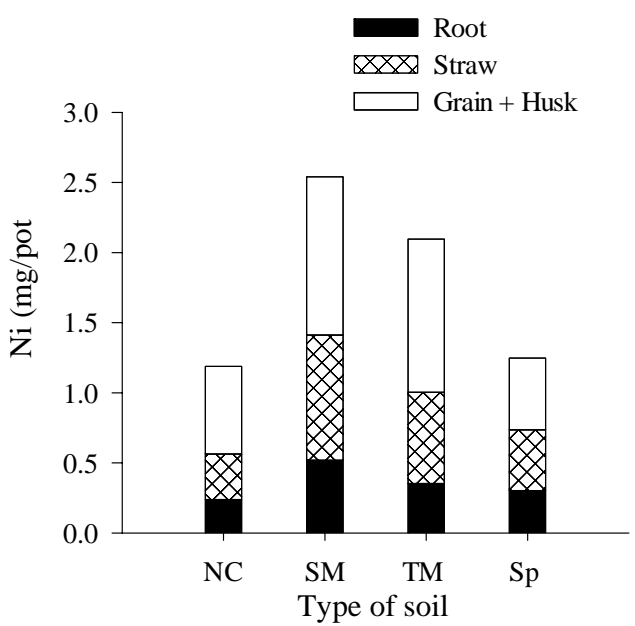

Fig 4. Uptake of $\mathrm{Cu}$ and $\mathrm{Ni}$ by Ipomoea and rice. 
The total concentrations of $\mathrm{Cu}$ and $\mathrm{Ni}$ in the soils were found to be significantly correlated $(r=0.92, \mathrm{p} \leq 0.01)$. Highly significant positive correlation $(r=0.83-0.99, \mathrm{p} \leq$ 0.01 ) between total and extractable ( $1 \mathrm{M} \mathrm{HCl}, 0.1 \mathrm{M} \mathrm{HCl}, 0.1 \mathrm{M}$ EDTA and DTPA) Cu was observed (Table 6). Highly significant correlation $(r=0.81-0.90, p \leq 0.01)$ was also observed between the total $\mathrm{Ni}$ and the extractable $\mathrm{Cu}$ fractions. Soil $\mathrm{pH}$ showed significant relationship with the $1 \mathrm{M} \mathrm{HCl}$ extractable and total metal concentrations, extractable and total metal concentrations. Soil organic matter did not show any significant relationship and hence these results are not reported in the text. Water, $\mathrm{NH}_{4} \mathrm{Cl}$ and $\mathrm{CaCl}_{2}$ extractable fractions of $\mathrm{Cu}$ and $\mathrm{Ni}$ showed poor and non-significant relationships. Correlations among the other extractable metal fractions were found to be positively significant in most cases.

Table 7. Correlation coefficients between extracted metal elements and their corresponding plant contents irrespective of soil types.

\begin{tabular}{|c|c|c|c|c|c|c|c|c|c|}
\hline \multirow{3}{*}{$\begin{array}{l}\text { Metal } \\
\text { element }\end{array}$} & \multirow{3}{*}{ Extractants } & \multicolumn{4}{|c|}{ Single extraction } & \multicolumn{4}{|c|}{ Sequential extraction } \\
\hline & & \multicolumn{2}{|c|}{ Ipomoea (Shoot) } & \multicolumn{2}{|c|}{ Rice (Grain) } & \multicolumn{2}{|c|}{ Ipomoea (Shoot) } & \multicolumn{2}{|c|}{ Rice (Grain) } \\
\hline & & $r$ & $p$ & $r$ & $p$ & $r$ & $p$ & $r$ & $p$ \\
\hline \multirow{8}{*}{$\mathrm{Cu}$} & Distilled $\mathrm{H}_{2} \mathrm{O}$ & -0.14 & 0.66 & 0.46 & 0.14 & -0.43 & 0.16 & 0.19 & 0.57 \\
\hline & $1 \mathrm{M} \mathrm{NH}_{4} \mathrm{Cl}$ & -0.05 & 0.89 & 0.63 & 0.03 & 0.68 & 0.02 & 0.02 & 0.95 \\
\hline & $0.01 \mathrm{M} \mathrm{CaCl}_{2}$ & -0.13 & 0.69 & -0.08 & 0.80 & 0.27 & 0.39 & 0.38 & 0.23 \\
\hline & 0.005 M DTPA & 0.17 & 0.60 & 0.78 & 0.003 & 0.26 & 0.42 & 0.18 & 0.58 \\
\hline & 0.1 M EDTA & -0.07 & 0.83 & 0.82 & 0.001 & 0.03 & 0.93 & 0.19 & 0.55 \\
\hline & $0.1 \mathrm{M} \mathrm{HCl}$ & -0.09 & 0.78 & 0.83 & 0.001 & 0.02 & 0.96 & 0.26 & 0.42 \\
\hline & $1 \mathrm{M} \mathrm{HCl}$ & -0.12 & 0.71 & 0.83 & 0.001 & 0.11 & 0.74 & 0.29 & 0.37 \\
\hline & Boiled aqua regia & -0.24 & 0.45 & 0.78 & 0.003 & & & & \\
\hline \multirow{8}{*}{$\mathrm{Ni}$} & Distilled $\mathrm{H}_{2} \mathrm{O}$ & 0.47 & 0.13 & 0.53 & 0.08 & -0.71 & 0.01 & -0.07 & 0.82 \\
\hline & $1 \mathrm{M} \mathrm{NH}_{4} \mathrm{Cl}$ & 0.41 & 0.19 & 0.04 & 0.91 & 0.38 & 0.22 & 0.03 & 0.93 \\
\hline & $0.01 \mathrm{M} \mathrm{CaCl}_{2}$ & 0.55 & 0.06 & -0.16 & 0.63 & 0.78 & 0.003 & 0.10 & 0.77 \\
\hline & 0.005 M DTPA & 0.51 & 0.09 & -0.08 & 0.81 & 0.04 & 0.91 & 0.11 & 0.75 \\
\hline & 0.1 M EDTA & 0.16 & 0.62 & 0.17 & 0.59 & -0.18 & 0.58 & 0.04 & 0.91 \\
\hline & $0.1 \mathrm{M} \mathrm{HCl}$ & 0.35 & 0.26 & -0.14 & 0.67 & -0.08 & 0.81 & 0.20 & 0.53 \\
\hline & $1 \mathrm{M} \mathrm{HCl}$ & 0.51 & 0.09 & -0.17 & 0.59 & 0.02 & 0.95 & 0.24 & 0.46 \\
\hline & Boiled aqua regia & 0.50 & 0.10 & 0.26 & 0.42 & & & & \\
\hline
\end{tabular}

$r=$ Correlation coefficient, $p=\mathrm{p}$ value, $\mathrm{n}=12$.

Copper content in rice grains showed highly significant $(\mathrm{p}<0.01)$ positive correlations with the total and most of the single extractable fractions in the soils, while for Ipomoea the relationships were mostly negative and not significant (Table 7). In general, poor correlations were observed between the concentrations of $\mathrm{Cu}$ and $\mathrm{Ni}$ in both the plant species and those in the soils and the relationships were mostly not significant. The 
positive relationships among the soil and plant metal contents could be related to heavy metal toxicities in both plants and animals through their entry into the food chain. Poor and negative correlations observed among the soil and plant metal contents might be due to differences in soil types, the nature of the plants concerned and the extent and type of industrial effluents.

The concentrations of $\mathrm{Cu}$ in the soils after harvest of both of the crops were found to be increased by 190, 635, 609 and 45 (for Ipomoea) and 135, 144, 118 and 8\% (for rice) in the NC, SM, TM and Sp soils, respectively (Fig. 5), while the concentration of $\mathrm{Ni}$ in the residual soils showed irregular pattern. The decreases in metal content in the soils after plant culture indicate accumulation of the elements into the plants. On the other hand, the increase in the concentration of $\mathrm{Cu}$ and $\mathrm{Ni}$ in soils was perhaps due to the release of endogenous metals from the plants, caused by the release of organic acid exudates from the plant roots.

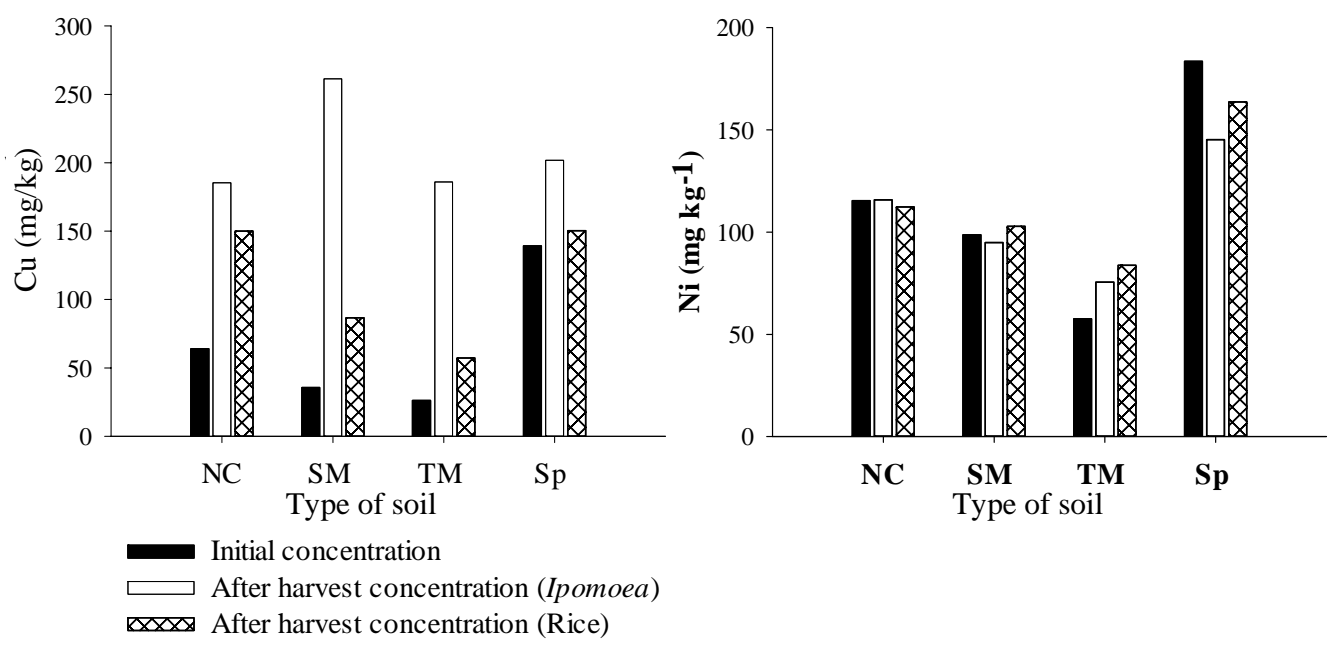

Fig. 5. Concentrations of $\mathrm{Cu}$ and $\mathrm{Ni}$ in the soils before and after harvest of the crops.

The results of the present study suggest that agricultural soils of Bangladesh in the vicinity of different industrial areas are at risk of heavy metal contamination/pollution. The concentration of $\mathrm{Cu}$ and $\mathrm{Ni}$ in the soils and the plant tissues and a strong correlation among the extractable metal fractions and metals content in the plants indicate the phytoavailability of the heavy metals. However, the assessment of the phytoavailability of the elements considered in this study was found to be dependent on the method of extraction, the crop and metal species, as well as the soil type. The present study indicates that a mild extractant such as $1 \mathrm{M} \mathrm{HCl}$ can be used to assess the phytoavailability of the heavy metals $\mathrm{Cu}$ and $\mathrm{Ni}$. 


\section{Acknowledgment}

The work was conducted as a part of research grant of Bangladesh University Grants Commission. The authors acknowledge it.

\section{References}

1. Chowdhury MTA, L Nesa, MA Kashem and SM Imamul Huq 2010. Assessment of the phytoavailability of $\mathrm{Cd}, \mathrm{Pb}$ and $\mathrm{Zn}$ using various extraction procedures. Pedologist 53(3): 80-95.

2. Joardar JC, MH Rashid and SM Imamul Huq 2005. Adsorption of lead ( $\mathrm{Pb}$ ) by soils and their clay fraction. J. Asiat. Soc. Bangladesh Sci. 31: 63-74.

3. Imamul Huq SM, NM Islam and M Das 2000. Effect of automobile exhausts on nutritional status of soil and plant. Bangladesh J. Soil Sci. 26: 103-111.

4. Kashem MA, BR Singh, T Kondo, SM Imamul Huq and S Kawai 2007. Comparison of extractability of $\mathrm{Cd}, \mathrm{Cu}, \mathrm{Pb}$, and $\mathrm{Zn}$ with sequential extraction in contaminated and noncontaminated soils. Int. J. Environ. Sci. Tech. 4: 169-176.

5. Ure AM 1996. Single extraction schemes for soil analysis and related applications. Sci. Total Environ. 178: 3-10.

6. Imamul Huq SM and MD Alam 2005. A Handbook on Analyses of Soil, Plant, and Water. BACERDU, University of Dhaka, Bangladesh. pp. 246.

7. Imamul Huq SM, S Al-Mamun, JC Joardar and SA Hossain 2008. Remediation of soil arsenic toxicity in Ipomea aquatica using various sources of organic matter. Land Contam. Reclam. 16: 333-341.

8. Krishnamurti GSR, PM Huang, KCJ Van Rees, LM Kozak and HPW Rostad 1995. A new soil test method for the determination of plant available cadmium in soils. Commun. Soil Sci. Plant Anal. 26: 2857-2867.

9. Ahnstrom ZS and DR Parker1999. Development and assessment of a sequential extraction procedure for the fractionation of soil cadmium. Soil Sci. Soc. Am. J. 63: 1650-1658.

10. Lindsay WL and WA Norvell 1978. Development of a DTPA soil test for zinc, iron, manganese and copper. Soil Sci. Soc. Am. J. 42: 421-428.

11. Council on Soil Testing and Plant Analysis (CSTPA) 1980. Handbook on Reference Methods for Soil Testing. University of Georgia, Athens, GA.

12. Australian and New Zealand Environment and Conservation Council (ANZECC) and Agriculture and Resource Management Council of Australia and New Zealand (ARMCANZ) 2000. Australian and New Zealand Guidelines for Fresh and Marine Water Quality. ANZECC and ARMCANZ, Canberra. pp. 1-103.

13. Mellum HK, AKM Arnesen and BR Singh 1998. Extractability and plant uptake of heavy metals in alum shale soils. Commun. Soil Sci. Plant Anal. 29: 1183-1198.

14. Domingo LE and K Kyuma 1983. Trace elements in tropical Asian paddy soils. I. Total trace element status. Soil Sci. Plant Nutr. 29(4): 435-452.

15. Kloke A 1980. Orientierungsdaten für tolerierbare Gesamtgehalte einiger Elemente in Kulturboden. Mitt VDLUFA. 1/III: 9-11. 
16. Imamul Huq SM and MN Islam 1999. Contamination of soil and plant by lead, zinc and other heavy metals from motor vehicle exhausts along a highway in Bangladesh. In: Contaminants and the Soil Environment: Proceedings of the Second International Conference on Contaminants and Soil Environment in the Australasia-Pacific Region, New Delhi, 12-17 December 1999, SIC-14. pp. 487-489.

17. Kabata-Pendias A 2011. Trace Elements in Soils and Plants. $4^{\text {th }}$ ed. CRC Press, Taylor \& Francis Group, Boca Raton. pp.105.

18. Cox RM and TC Hutchinson 1979. Metal co-tolerances in the grass Deschampsia cespitosa. Nature 279: 231-233.

19. Farago ME and JT O'Connell 1983. Soil and plant concentrations of cadmium and zinc in the vicinity of a smelter. Miner. Environ. 5: 71-78.

20. Hogan GD and DL Wottom 1984. Pollutant distribution and effects in forests adjacent to smelters. J. Environ. Qual. 13: 377-382.

21. Kashem MA and BR Singh 1999. Heavy metal contamination of soil and vegetation in the vicinity of industries in Bangladesh. Water Air Soil Pollut. 115: 347-361.

(Manuscript received on .......................; revised on .........................) 